Instructions for authors, subscriptions and further details:

http://rise.hipatiapress.com

\title{
Higher Education and Funding Strategies for Knowledge Generation of Releance: A Comparative Study Between Mozambique and Brazil
}

Pedro Uetela ${ }^{1}$

1) University of Western Cape, South Africa

Date of publication: February $25^{\text {th }}, 2019$

Edition period: February 2019-June 2019

To cite this article: Uetela, P. (2019). Higher Education and Funding Strategies for Knowledge Generation of Releance: A Comparative Study Between Mozambique and Brazil, International Journal of Sociology of Education, 8(1), 28-44. doi: 10.17583/rise.2019.3539

To link this article: http://dx.doi.org/10.17583/rise.2019.3539

PLEASE SCROLL DOWN FOR ARTICLE

The terms and conditions of use are related to the Open Journal System and to Creative Commons Attribution License (CC-BY) 


\section{Higher Education and Funding Strategies for Knowledge Generation of Releance: A Comparative Study Between Mozambique and Brazil}

Pedro Uetela

University of Western Cape

(Received: 8 June 2018; Accepted: 25 October 2018; Published: 25 February 2019)

\section{Abstract}

Research has shown a strong correlation between the longevity of the African continent and the origin of higher education. However, most of the African countries today including Mozambique still lag behind with regards to higher education placement in the international ranking and competition. Since funding strategies of knowledge generation and research incentive are considerably seen as key factors that enhance university performance and success, for most of African countries the insufficiency of either political or economic independence has contributed for a sharp marginalization of higher education associated mainly with reliance on external donors that became sources of steering universities. Drawing from literature review and historical evidence (data), this paper aims at investigating the development process of Mozambican and Brazilian higher education. It both argues and concludes that experiences from Brazil concerning maximization of research funding agencies, which strengthen higher education, can be contextualized in Africa as a means of re-inventing universities after decades of depreciation

Keywords: higher education, funding, Brazil, Mozambique 


\section{Educación Superior y Estrategias de Financiación para el Conocimiento de la Generación del Alivio: Un Estudio Comparativo Entre Mozambique y Brasil}

Pedro Uetela

University of Western Cape, South Africa

(Recibido: 8 Junio 2018; Aceptado: 25 Octubre 2019; Publicado: 25 Febrero 2019)

\section{Resumen}

Las investigaciones han demostrado una significativa relación entre la longevidad del continente africano y el origen de la educación superior. Sin embargo, la mayoría de los países africanos, incluido Mozambique, se han quedado atrás en cuanto a competitividad internacional e inclusión en el ranking mundial de educación. Determinar estrategias para la generación de conocimiento e iniciativas de investigación, son vistos como factores claves para mejorar el desarrollo y el éxito universitario. En la mayoría de los países africanos, la insuficiencia en sus políticas y la falta de independencia económica ha llevado a una marginalización de la educación superior y a una dependencia de patrocinadores externos. Considerando literatura al respecto y mediante revisión de evidencia histórica, este artículo pretende abordar el proceso de desarrollo de la educación superior en Mozambique y Brasil. Se argumentará que la experiencia de Brasil, en relación a la maximización de las agencias de financiamiento y el fortalecimiento de la educación superior, puede contextualizarse en África y significar una reinvención de las universidades, luego de décadas de marginalización.

Palabras clave: educación superior, financiación, Mozambique, Brasil. 


\section{Uetela-Higher Education and Funding Strategies}

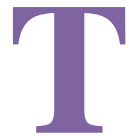

eferra and Altbach (2004) consider the conception of higher education (HE) in Africa as ancient as the construction of the pyramids of Egypt. Their argument is both theoretically and empirically substantiated by the permanence of universities such as Ez-Zitouna Madrassa in Tunis instituted in 732 Annum Domini (AD), Karaouine of Fez-Marrocos established in 859 (AD), Al-Azhar Cairo-Egypt in 970 and Sankore in Timbuktu-Mali, which appeared in 1100 (AD). The above captioned theory (which proves the longevity of HE on the continent) contradicts the dominant view of the West (Europe) as the fountain of higher learning institutions. There are several reasons that justify this position of Africa rather than Europe as the genesis of $\mathrm{HE}$ considering that in the context of Europe, the premier institutionalization of higher learning is strongly associated to universities such as Bologna, going back to 1088 (A.D), Oxford (1096), Salamanka instituted in (1136) and the university of Paris is assumed to date from $1160 \mathrm{AD}$. This latter and new model of universities (the European) envisaged a novel typology of categories of defining science that are currently applied within African universities as opposed to those that existed before colonization (Cloete, et al, 2010, p. 2).

Therefore, despite earlier existence of a kind of higher education in the African continent, research indicates that undoubtedly due to constraints such as the conquest of the region through colonization, the major forms of universities that emerged initially and before the 15th century (era of European settlement), did not maintain continuity and consequently the preestablished categories of scientific definition and development in an indigenous domain became extinct. Furthermore, the modern university that appeared with domination narrowed the possibilities of enforcing indigenous models of epistemology, which were developing in parallel with native higher learning institutions in Africa since the $6^{\text {th }}$ century, a period universities are accounted to have emerged by the first time. As data indicates, the contemporary African university inherited from colonization is only attributed to dominate in the continent shortly before the independence of African states especially after the mid- $20^{\text {th }}$ century. This is hypothetically due to the fact that at the early moments of European settlement, either education or the establishment of higher education did not become a major concern for Europe. Instead, the initial main objective with the continent rested essentially upon resources exploitation, domination and imposition of 
the European cultural capital.

In Mozambique, specifically, the establishment of higher education is only attributed to commence in 1962, that is, almost a decade before the declaration of its independence and after approximately 450 years of Portuguese presence in the country. In addition, both Uetela (2016) and Cloete et al (2011) concur with the theory that, economic independence either in Mozambique or in many other African countries is still a process under construction and steering higher learning has been affected in this perspective. The insufficiency of African states to finance higher education towards the strategies of development (transformation) has considerably affected the creation of research agencies in order to build and strengthen universities' capacity.

The National Fund for Investigation (FNI) and the Centre for Higher Education Development (CESD) are recent institutions that have neither been able to acquire nor to possess sufficient income that contributes to foster university development based on research projects that emerge within HEIs. Furthermore, the institution of effective public policies for higher education suggested by these agencies is still an on-going process and their lineaments with the social functions of universities remains contradictory (Muller, 2014, p. 255).

However, this is not the case in Brazil where entities such as the coordination for the advancement of higher education personal (CAPES), the national council for research development (CNPQ) and the foundation for research support of the state of São Paulo (FAPESP) play at least a threefold role in both innovation and definition of indexes that account for relevance of universities considering that (i) they have consistently empowered both progress and research in universities through investment initiatives in projects that instigate competition for finance within higher education institutions. In addition, the same agencies (ii) have evidenced a strong correlation between HE performance and the nexus between teaching and research as strongly dependent on funding. Lastly, they are also (iii) deemed as tools through which the link between teaching and research is assured within higher education. Under this theoretical framework the distinctive higher education and historical institutionalization of systems of higher education in the two countries entail differentiated funding mechanisms and consequently incomparable achievements in the two contexts as the article 


\section{Uetela-Higher Education and Funding Strategies}

outlines in the subsequent sections.

\section{Methodology}

Given that the main interest in this research is to provide an overview concerning funding strategies in two countries especially Mozambique and Brazil and indicate the magnitude at which this has strongly accounted for differentiated outcomes, methodologically the article applies a comprehensive review of literature with greater emphasis for Cloete et at (2011, 2010); Uetela (2016); Zavale \& Macamo (2016); Langa (2013); Lulat (2013) and Gibbons et al (1994). Furthermore, it analyses policy documents of the two contexts concerning the development of higher education and statistical data to comprehend the extent to which the inception of research funding politics explains success in one country and struggle for university relevance on the other (Brazil and Mozambique) respectively.

\section{The Inception of Higher Education in Mozambique and Funding Politics}

At its inception, HE in Mozambique emerged as a means of empowering the Portuguese intellectual elite inhabiting in the country. After independence $\mathrm{HE}$ became nationalized and a considerable number of indigenous citizens also became both theoretical and legally privileged though empirically access to HE still benefitted either the elite nationals or those who had undergone a process of assimilation during the colonial regime. In the 1990s following the liberalisation of economy private higher education emerged in Mozambique as the law $1 / 93$ of $24^{\text {th }}$ June licensed the rise of universities of such category. The above captioned arguments revitalize both genesis and development of Mozambican higher education at least in a threefold timeframe (i) before independence-when only Portuguese elites were admitted to higher education (ii) post independence when higher education was theoretically deemed as public in line with the socialist political ideology and (iii) the liberal époque which led to privatization of higher education.

This historical background and struggle related to the Mozambican higher education may account for the actual distinctive politics of higher 
education funding as Langa (2013) describes those in terms of (i) state budget, (ii) donor agencies and (iii) income generation. Though after independence and liberalization of the economy the number of both higher education institutions and population admitted to higher education has significantly risen from 1 Mozambican student in 1966 to approximately 20 thousands in 2015 and from 1 university to nearly 50 HEIs in the same period, the strategies have been slow at enhancing social transformation considering that participation remained elitist at 3\% average (Clothe, 2010, p. 30 and Uetela, 2016, p. 12).

Both rapid access and admission to $\mathrm{HE}$ in this perspective did not become necessarily linked to greater achievements considering the statistical drift of participation as an index that determines performance and relevance. In the case of Mozambique this figure remained classified between $1 \%$ to $5 \%$ of participation either before or after independence, which is categorized under an elitist $\mathrm{HE}$ in a process of self-determination.

The struggles of modern African university is also attributed to the fact that its establishment either in Mozambique or in other countries coincided with the oil world crisis of the 1970s and African states including Mozambique were admonished to both manage and lead universities under recession theory approach. Furthermore, in the case of the latter country (Mozambique) the liberalisation of the economy and privatisation of higher education was seen as a consequence of insufficiency of the state to steer its institutions including universities. Such inability of the Mozambican state's funding mechanisms (see 2500 USD for the state to maintain each single student in higher education) especially during the 1990s evidenced by rapid growth of private $\mathrm{HE}$ imposed an inevitable sharp reliance on donor agencies with special emphasis for the World Bank (WB) and the International Monetary Fund (IMF) to finance both African states and universities. In Mozambique such dependence is often seen as the policy that maintained continued existence of the system in the country through assistance on state budget as Cloete (2011) and Assie-Lumumba (2005) evidence for the majority of African nation states.

As it is worth remarking, Uetela (2016) put it that at the same period of the 1990s the Mozambican state was urged to abandon HE in order to invest in primary and secondary education considering that the return indexes at the former level were lower than investment. Under the guidance of this policy 


\section{Uetela-Higher Education and Funding Strategies}

strategy donor agencies steered education on basis of return, which led to marginalization of universities in the country. The view is further evidenced both theoretically and empirically by recent statistical data on research funding for Africa in the following terms:

In order to see how efforts of African governments would falter even if higher education was considered as a means to improve economic growth, from the mid-1980s until the late 1990s, higher education spending was reduced for Africa, a period in which there was a need for more investment. In the late1980s, the World Bank spending on higher education in Africa was $17 \%$ of the total higher education funds, but by the 1990s it had suffered a decline of $10 \%$ to $7 \%$. Such reductions in spending undoubtedly affected the progress of universities in the continent, which seems to support the thesis that failing to follow the political, economic and social models of the Western ideologies leads to underdevelopment [...] (Uetela, 2016, p. 20-22).

Since lack of national initiatives to support the development of higher education in the country associated with dependence on donor agencies in a period priorities were conflicting (steering primary and secondary education versus the necessity of expanding higher education) has affected the road map for development of universities in Mozambique and delayed its contribution for social change. The fact that only $3 \%$ of the total (HE) population aged are admitted, might be justified by the burden of the state to fund universities and turn it as a public good. The actual placement of Mozambican HE and the rest of African countries in comparison with other contexts where Brazil is located is represented bellow in line with income. 




Figure 1. Placement of Mozambique (in Sub-Saharan Africa) and Brazil (South America and the Caribbean) from the mid-1960s to mid 2000s Source: (Interpretation of Bloom; Canning \& Chan 2006, p. 7 Apud Uetela, 2016, p. 22).

From the above table, income has a strong influence on the position and international competition of HE. The case of Mozambique and Africa in general is mingled within this scenario where the insufficiency of economic independence, national states and local agencies to fund higher education has positioned native universities in the above-represented platform. After describing the situation of Mozambique it then becomes urgent to analyse the case of Brazil and see how the latter country has invested in higher education and what steering politics are at place. Furthermore and subsequently to the Brazilian situation it is possible to outline the forms through which Mozambique can learn and contextualize the processes of constantly re-inventing its HE. 


\section{Uetela-Higher Education and Funding Strategies}

\section{The Case of Brazil: Higher Education and Funding Strategies}

Uetela (2017) is one of the proponents of the argument that the inception of HE in Brazil goes back to the early 1930s and its rapid success is attributed to the binding efforts between the European and American social contexts of structuring both teaching and learning within Brazilian universities. His position is paralleled to Vianna (1997) and Dos Santos (1963) when they address the geneses of social sciences and HE in Brazil as a long historical reality, which can be traced back to the establishment of the first Brazilian republic and reorganization of the state in the 1930s. It was during the above contexts (the emergence of the first republic) that the study of sociology in secondary levels was established; the school of sociology and politics of the university of São Paulo initiated and the university of São Paulo (USP) was created as a consequence in 1934. This early institutionalization of higher education in the context of Brazil as compared to Mozambique might have implications upon achievements of higher learning in the two countries.

The case of Brazil shows that the quest for rationality is aligned with the establishment of the state of well-being as Fernandes (1980) further describes the rise of universities and study of social sciences as a means of maximization of rational thought at the period of inception of HE in the country. The argument corroborates with Abreu (1990) in his analysis concerning order and progress in Brazil. Thus, it appears undoubtedly that under such historical construction of HE in the country is the appropriation of Comte's perspective that scientific knowledge is the premier science, which empowers a national state. This way of reasoning led to the necessity of institutionalization of universities as the legitimate agencies that confer knowledge through rational scientific categories. In a similar perspective at the international level Castells (2001) considers the mission of any HEI in terms of (i) selection and instruction of the dominant elites, (ii) instruction of the labour force (iii) and legitimacy of appropriate knowledge of relevance. All these attributes are key for national state empowerment and Brazil appears to have initially impregnated these in the national state building and its institutions' enforcement (Castells, 2001, p.1). 
Henceforth, drawing from the perspective of Abreu (1990) the chronological order concerning the conception of Brazilian HE which maximized rational/scientific thought can be as follow (i) USP as the fountain of rationalization of social sciences in 1934, (ii) the university of Brasilia in 1937, Brazilian centre for physics research in 1949 and the postgraduate program in social sciences at the Federal University of Rio de Janeiro, just to outline the premier existing institutions that instigated academia in the country (Vianna, 1997, p. 199-206 and Schwartzman, 1981, p. 16).

In the next iteration, the development of HE in Brazil is also interpreted into two folds considering the merging strategies between the European and American models of universities justified by the presence in the above HEIs of staff from both American and European schools of thought. Furthermore, the existence of research incentive agencies that were subsequently applied to foster the nexus between theory and practice is another policy inherited from the two schools and has empowered higher learning in this country. Through research incentive agencies including (i) Financiamento de Estudos e Projetos (FINEP), (ii) Coordenação de Aperfeiçoamento do Pessoal de Nivel Superior(CAPES), (iii) Conselho Nacional para o Desenvolvimento da pesquisa(CNPQ) and (iv) Fundação de Amparo à Pesquisa do Estado de São Paulo (FAPESP), empirical problems are investigated within universities based on application of research funds and projects of relevance (Vianna, 1997, p. 206).

The premier initiatives of instituting these programs go back to the 1950s though at the beginning were designed to foster disciplines related to the domain of hard sciences. Due to high demand and necessity of empowering both hard and soft sciences, the project extended to finance social sciences associated programs as a means of enhancing the development of $\mathrm{HE}$ and arenas of knowledge generation as a whole. In reference with Miceli (1995), the author further considers the success of the Brazilian agencies and steering politics of $\mathrm{HE}$ at least in social sciences in the following terms.

Os anos 70 e 80 marcaram o período áureo do apoio financeiro e institucional prestado por essas agências de fomento às ciências sociais brasileiras. No caso da CNPQ, por exemplo, a crescente 
incorporação dessas disciplinas entre as prioridades de atendimento a partir de meados dos anos 70 foi se traduzindo numa série de mudanças nas modalidades internas de operação. A quando da implantação dos comités assessores, as dezessete subáreas e disciplinas em ciências sociais foram todas alojadas em apenas dois comités, depois tendo se elevado a quatro em 1982 e a seis em 1984. Na primeira metade dos anos 80 , a expressiva abertura aos cientistas sociais no CNPQ pode ser confirmada através das taxas de expansão da quantidade e do montante financeiro de bolsas e auxílios, modalidades preferenciais de apoio dessas agências. [...]. Em termos do número de auxílios à pesquisa, concedidos pela mesma agência entre 1972 e 1979, a área de ciências humanas e sociais cresceu muito mais que todas as demais, logrando uma taxa média de crescimento anual de $38,7 \%$ comparada aos $14,8 \%$ das áreas concorrentes. A posição das ciências sociais consolidou-se ainda mais nos anos 80 conforme demonstra a evolução do número de bolsas no país e no exterior nesse período, as ciências humanas e sociais tendo alcançado a taxa anual de crescimento de $21,38 \%$, a mais elevada dentre todas as áreas cujo crescimento em conjunto não ultrapassou $8 \%$. A presença global do CNPQ passou de 4\% em 1974 para 16\% em 1984. A Fapesp começou desde os anos 60 a conceder bolsas e auxílios de pesquisa às ciências sociais e às humanidades em geral, sendo que esse montante tem girado em torno de $12 \%$ dos recursos disponíveis, evidenciandose desde 1982 uma tendência inequívoca à expansão da demanda por recursos nas áreas mencionadas. [...] A Finep começou o financiamento das ciências sociais em 1974 atendendo apenas poucas instituições cariocas [...], (Miceli, 1995, pp. 23-4 apud Uetela, 2017, p. 18)

The above paragraph can be translated as follow "The 70s and $80 \mathrm{~s}$ signalled a success in terms of funding and institutional support provided by these agencies, which empower the prosperity of Brazilian social sciences. In the specific case of CNPQ, for instance, the incorporation of social sciences as a priority especially from the early 1970s has led to considerable changes in the internal models of operation. When this initiative was launched, the 17 sub-areas and disciplines of social sciences that existed at 
the moment all merged into two committees. Later on this number sharply increased to 4 in 1982 and finally to 6 in 1984. In the first half of the 1980s the accommodation of social scientists with the CNPQ is evidenced by a significant increase either over quantity in the financial amount of scholarships or support considered as the main mechanism of aid applied by these agencies. In terms of statistics in research support offered by the CNPQ between 1972 and 1979 the field of social sciences and humanities grew considerably as compared to other arenas of knowledge generation. The average growth index reached $38,7 \%$ as compared to the $14,8 \%$ applied in other domains. The rank of social sciences continued to dominate especially in the 1980s according to the statistical evolution of scholarships both within Brazil and abroad reaching an annual growth of $21,38 \%$ the highest among all fields of knowledge production of which growth did not go beyond $8 \%$ increase. The global presence of CNPQ grew from $4 \%$ in 1974 to $16 \%$ in 1984 . FAPESP started from the 1960 s offering research support scholarships in social sciences and humanities in general. Such amount has been estimated in $12 \%$ of available resources, evidencing since 1982 an undeniable expansion of resources necessity in the fields above mentioned. FINEP launched its initiative of financing social sciences in 1974 with special emphasis for few institutions from the state of Rio de Janeiro" [...], (Miceli, 1995, pp. 23-24 Apud Uetela, 2017, p. 18)

The statistical data concerning the Brazilian revitalization of HE through steering politics account for a differentiated process of both institutionalization and development of universities between the two countries. From the data, Mozambique is urged to maximize these successful experiences from Brazil as a means of fostering financial independence and fund higher learning through local initiatives as this research highlights to be the final considerations and urgent recommendations for policy action.

\section{Results and Policy Action}

The data from Mozambique and Brazil concerning HE account for different perspectives with regards to funding mechanisms that can be explained from various perspectives. Furthermore, it is evidenced that Mozambique can maximize these successful experiences from the latter country herein analysed (Brazil) in order to empower its HE system towards development 
considering the number of reasons that nurture the two distinctive achievements. Whereas $\mathrm{HE}$ in Mozambique was implemented from one perspective (from inheritance of its colonial master Portugal) and became often teaching oriented rather than theoretical and practically concerned, in Brazil this occurred in a contrary conception. In the latter country and in compliance with the data presented throughout the paper the inception of $\mathrm{HE}$ results from merging efforts between the European and American schools of thought. At its establishment $\mathrm{HE}$ in Brazil privileged the link between teaching and research immediately, which did not occur in the former nation (Mozambique). Furthermore, research and statistical data on the geneses of HE in the two countries show that whereas in Brazil universities are novel in comparison with the context of Europe and America considering that the premier institutions of higher learning appeared during the constitution of the first republic in the early 1930s, in Mozambique the establishment of universities is much newer as they initiated in 1968 upon the institution of the university of Lourenço Marques with the purposes of serving the Portuguese elite that lived in the country (Rosário, 2013, p. 1). In addition, in Mozambique the steering process of HE occurs in a variety of traditional means especially through income generation, tuition fees, state budget and donor agencies a view which evidences that higher learning in the country is still at the stage of its self-construction and lack of national agencies capable of steering universities towards public higher good has led to a lagging behind of HEIs in the global competition. The only mention of the National Research Investigation of Mozambique can evidence the analogy "run while others walk" stated herein this article to explain that the pace at which the Mozambican $\mathrm{HE}$ is found at, forces it to run in order to catch up with Brazil which is now at the walking stage when this latter nation is compared to the African country (Mkandawire, 2011).

The argument of urgent priority for policy change in Mozambique can be supported by the evidence that the dominance of research funding agencies in Brazil has led to competition between higher education institutions and as a result contributed to the empowerment of teaching and research nexus which positions HEIs at a higher level when compared to Mozambicans. In the case of Mozambique insufficient economic independence appears to have influenced sharply the magnitude of dependence from international donors in order to support the continued existence of its HE. However, 
whereas in Brazil both political and economic freedoms have been aligned, in the latter country this scenario did not yet occur at the level of the former nation. Hence, further policy initiatives of financial independence and establishment of additional research funding agencies is recommended to be the main priority for Mozambique to catch up in the running process. The main steering mechanism at place with emphasis on tuition fees privileged by Mozambique where the majority of the population is still living under the line of poverty, increases social inequalities and fosters determination of access to $\mathrm{HE}$ in line with income.

As a result, from the above strategy HE in the country (Mozambique) is moving towards greater levels of privatization in the sense that the models of funding at place shift priorities from university as a common good for it to be deemed as a private value.

Therefore, if knowledge is the main instrument of transformation and universities are the legitimate institutions, which confer such science, in the case of Mozambique there is a need of investing in HE through strategies that empower teaching-research nexus and integrate the majority of the population aged to access HE but are still alienated from it.

As compared to Mozambique, Brazil has succeeded in both funding and empowering its HEIs towards development and invests in policies of access to the majority of the population willing to enter university though it might not be at the level desired yet in terms of inclusion. Recent agreements that are being established between African universities and Brazilian are considered to be new equations that Mozambique can adhere in order to empower both its HE system and the establishment of research networks. This initiative might influence the quest for the necessity of privileging the triple helix (State-University and Industry) cooperation, which has sharply dawned in most HE systems internationally. The new coordination and necessity of cooperation between the three stakeholders, implies that mutual efforts are indispensable for university success. Therefore, universities being sources of knowledge generation can determine the politics that are adequate through research and support the state in implementing those. The case of increment on research funding agencies becomes then compelling for the Mozambican government and universities in order to lessen financial dependence from external donors for HE subsistence in the country. 


\section{References}

Abreu, M. (1990). A Ordem do progresso: Cem anos de política económica republicana 1889-1989. Rio de Janeiro: Editora Campus.

Assie-Lumumba, N. (2005). Higher Education in Africa: Crises, Reforms and Transformation. Council for the Development of Social Science Research in Africa, Dakar, Senegal, 2005. Retrieved from https://www.codesria.org

Bloom, D.; Canning, D. \& Chan, K. (2006). Higher education and economic development in Africa. Human Development Sector. Harvard: Harvard University Press.

Castells, M. (2001). Universities as Dynamic Systems of Contradictory Functions. In Muller, J et al (Ed). Knowledge Production and Contradictory Functions in Higher education. Cape Town: African Minnds.

Cloete, N. et al. (2011). Universities and Economic Development in Africa. Western Cape: Chet Publications.

Cloete, N. et al. (2010). Historical Development of Higher Education in Africa: Politics and Democratization. Higher Education Masters in Africa Course Reader, Cape Town: University of Cape-Town press. Dos Santos, W. (1963). Introdução ao estudo das contradições sociais no Brasil. Rio de Janeiro: Instituto Superior de Estudos Brasileiros. Fernandes, F. (1980). Desenvolvimento Histórico Social da Sociologia no Brasil. In Florestan Fernandes (Eds) A Sociologia no Brasil (pp. 2549) Rio de Janeiro: Petrópolis Vozes.

Gibbons, M. et al. (1964). The New Production of Knowledge. The Dynamics of Science and Research in Contemporary Societies. California: Sage Publications.

Langa, P. (2013). Higher Education in Portuguese Speaking Countries. A five country baseline study. Cape Town: African Minds.

Lulat, Y. (2003). The development of higher education in Africa. A historical survey. In Teferra, D \&Altbach, P. (org) African Higher Education: An international Reference handbook (pp. 15-31) Bloomington: Indiana University Press.

Mkandawire, T. (2011). Running while others walk. Knowledge and the challenges of Africa's Development. [lecturevideo]

Miceli, S. (2005). História das Ciências Sociais no Brasil. In Sérgio Mceli 
(Eds) História das Ciências Sociais no Brasil. São Paulo: Editora Sumaré, $2^{\text {a }}$ edition.

Muller, J. (2014). Every picture tells a story: Epistemological access and knowledge. Education as Change, Education as Change, 18(2), 255269. doi: 10.1080/16823206.2014.932256.

Rosário, L. (2013). Ensino Superior na África. Universidades Moçambicanas e o futuro de Moçambique. Revista Unicamp, 10, 4655

Schwartzman, S. (1981). Ciência, Universidade e Ideologia: A política do conhecimento, Rio de Janeiro: Zahar Editora.

Teferra, D \&Altbach, P. (2004). African Higher Education: Challenges for the 21st Century. Journal of Higher Education, 42, 21-50, 2004.

Uetela, P. Brasil-Moçambique: Uma análise comparativa da institucionalização das ciências sociais.Revista de Estudios Brasilenos, 4(6), 18-31.

Uetela, P. (2016). Higher Education and Development in Africa. London: Palgrave Macmillan 2016.

Uetela, P. (2015a) Evaluating the implementation of Free Primary education Policy in Mozambique. Equity and efficiency approaches.Revista Electrónica de Investigação, Filosófica, Ciência e Tecnologica, 2(1), 14-30.

Uetela, P. (2015b). Higher Education and Economic Growth in Mozambique: Some evidence, RISE: International Journal of Sociology of Education, 4(3), 276-294. doi: 10.17583/rise.2015.1751

Vianna, L. (1997). A institucionalização das ciências sociais e a reforma social: Do pensamento social à agenda americana de pesquisa. In Vianna Lúcio. (Eds). A Revolução Passiva (pp. 173-222). Rio de Janeiro: Revan.

Zavale, N. \& Macamo, E. (2016). How and what knowledge do universities and academics transfer to industry in African low-income countries? Evidence from the stage of university-industry linkages in Mozambique. International Journal of Educational Development, Elsevier, 49, 247-261, 2016. Retrieved from https://ideas.repec.org/a/eee/injoed/v49y2016icp247-261.html 
Pedro Uetela Is a post-doc research fellow in Higher Education Policy and Innovation Studies at the University of Western Cape (Institute of Post School Studies), South Africa, in partnership with Eduardo Mondlane University and the Department of Learning in Engineering Sciences (KTH-Sweden)

Contact Address: uetelaha@yahoo.com 